\title{
PERANAN PROMOSI DALAM MENINGKATKAN JUMLAH NASABAH TABUNGAN PADA BANK NAGARI CABANG SAWAHLUNTO
}

\author{
Tetra Yanti Eltika, Mariani St.B Tanjung \\ Akademi Keuangan dan Perbankan Padang \\ mstbtanjung@gmail.com
}

\begin{abstract}
ABSTRAK
Penelitian ini bertujuan untuk mengetahui Jenis Promosi apa yang dilakukan oleh Bank Nagari Cabang Sawahlunto dan sejauh mana peranannya didalam meningkatkan jumlah nasabah tabungan. Teknik pengelolaan dan analisa data yang digunakan adalah teknik deskriptif analisis yaitu metode penelitian dengan mengumpulkan dan menyajikan data disertai analisis yang dapat memperjelas gambaran mengenai objek yang diteliti. Data yang digunakan dalam penelitian ini adalah data yang berhasil diperoleh, dikumpulkan selama penelitian, kemudian diproses untuk dianalisis lebih lanjut dengan mengunakan dasar-dasar teori yang ada sehingga dapat memperjelas gambaran mengenai objek yang diteliti. Produk Bank Nagari dalam menghimpun dana masyarakat adalah dalam bentuk tabungan yang terdiri dari tabungan sikoci, tabungan Haji Tahari Mabrur, Simpeda, dan lain-lain. Dalam meningkatkan jumlah nasabah tabungan Bank Nagari Cab. Sawahlunto melakukan promotion Mix atau bauran promosi yakni: advertising, sales promotion, publicity, personal selling. Dalam hal lain mencakup pemberian undian-undian pada berbagai jenis tabungan, pemberian cendera mata, serta melakukan promosi dengan cara memberikan beasiswa terhadap pendidikan. Dalam arti kata biaya promosi belum berpengaruh secara signifikan terhadap peningkatan jumlah nasabah tabungan. Hal ini terlihat pada peningkatan dan penurunan jumlah nasabah dari tahun ke tahun.
\end{abstract}

Kata Kunci: Promosi, Nasabah

\section{PENDAHULUAN}

Dalam melakukan kegiatan perekonomian dibutuhkan dana yang cukup besar. Melihat kondisi perekonomian Indonesia sekarang yang semakin lesu dan memprihatinkan serta merosotnya nilai mata uang rupiah. Oleh karena itu peranan lembaga perbankan sebagai fasilitator pembangunan sangat penting, yaitu memberikan jasa dalam membiayai usaha-usaha produksi yang pada akhirnya dapat meningkatkan pertumbuhan ekonomi.

Bank merupakan lembaga keuangan yang mempunyai usaha pokok yaitu menghimpun dana dari masyarakat dalam bentuk simpanan dan menyalurkan kembali kepada masyarakat dalam bentuk pinjaman atau kredit. Penyediaan dana 
yang bersumber dari masyarakat bagi perbankan khususnya berupa dana giro, tabungan, deposito perlu ditingkatkan untuk disalurkan kembali kepada masyarakat dalam sektor yang produktif. Salah satu fungsi utama bank ialah sebagai lembaga perantara (Intermediasi) antara masyarakat yang kelebihan dana dengan masyarakat yang membutuhkan dana, dan keuntungan Bank diperoleh dari selisih harga jual dan harga beli dana tersebut dikurangi dengan biaya operasional. Dengan demikian Bank harus mampu menempatkan dananya yang telah dihimpun dalam bentuk penempatan dana yang paling menguntungkan adalah dalam bentuk kredit.

Berdasarkan pasal 5 Undang-Undang No 10 Tahun 1998 tentang perubahan Undang-Undang No. 7 Tahun 1992 tentang perbankan, ada 2 jenis Bank yaitu Bank Umum, dan Bank Perkreditan Rakyat. Bank umum adalah bank yang melaksanakan kegiatan usaha secara konvensional dan atau berdasarkan prinsip syariah yang kegiatannya memberikan jasa lalu lintas pembayaran. Bank umum tidak hanya berusaha di satu bidang usaha, tetapi juga dalam berbagai bidang usaha bank lainnya. Bank umum diperkenankan memberikan kredit dalam usahanya dan lebih menekankan perkreditan jangka pendek, yang dimaksud perkreditan jangka pendek adalah mendiskonto wesel-wesel serta surat-surat berharga, jual beli wesel dalam negri dan luar negri.

Ditinjau dari usaha Bank umum bergerak bukan hanya dalam sektor perdagangan dalam arti yang luas, tetapi juga sektor perindustrian, pertanian, perkebunan, pelayaran bahkan turut juga memberikan kredit kepada instansi pemerintah. Mengingat bidang usaha yang luas itu, maka kedudukan Bank umum telah mendapat kedudukan yang sangat penting. Bank umum merupakan salah satu mata rantai lalu lintas pembayaran dalam tata ekonomi modern.

Sedangkan Bank Perkreditan Rakyat (BPR) adalah Bank yang melaksanakan kegiatan usaha secara konvensional atau berdasarkan prinsip syariah yang dalam kegiatannya tidak memberikan jasa lalu lintas pembayaran.Selain itu dalam dunia perbankan juga sangat dibutuhkan kemajuan teknologi, salah satunya adalah computer. Dengan adanya computer informasi yang di perlukan dapat dihasilkan dengan lebih cepat dan akurat.

Bank Nagari sebagai Bank Pembangunan Daerah Sumatera Barat merupakan salah satu perusahaan perbankan yang dimiliki oleh pemerintah daerah Sumatera Barat yang sekarang ini termasuk salah satu Bank yang berkembang pesat, bank ini juga telah menggunakan computer dalam pengolahan datanya.Selama ini Bank Nagari dalam kegiatan operasionalnya sudah menggunakan system OLIBS (On-Line Integrated Banking Sistem). OLIBS dipergunakan oleh Bank Nagari untuk membantu dalam memberi pelayanan informasi guna keperluan eksternal maupun internal Bank Nagari itu sendiri. Namun demikian pengguna program aplikasi manual masih tetap dipergunakan dalam kegiatan operasionalnya.

Pada dasarnya OLIBS merupakan program aplikasi yang mengikuti perkembangan dan kemajuan teknologi informasi saat ini. Bank Nagari sudah memiliki program aplikasi untuk transaksi penghimpunan dana dan penyaluran dana. Begitu juga dalam kegiatan promosi, promosi adalah informasi atau 
persuasi satu arah yang dibuat untuk mengarahkan seorang atau organisasi kepada tindakan yang menciptakan pertukaran dalam pemasaran.

Meningkatnya kegiatan usaha dibidang jasa yaitu dengan meningkatnya produk-produk yang dihasilkan baik dalam segi kualitas maupun kuantitasnya, maka sebagai akibatnya akan menimbulkan suatu kondisi yang disebut persaingan. Dalam menghadapi persaingan Bank dituntut untuk mengarahkan sumber daya yang ada, baik dibidang pemasaran maupun non pemasaran,dalam hai ini juga diperlukan media-media teknologi informasi.

Berhasilnya usaha pada perbankan ini terletak pada pengelolaan manajemen pemasarannya. Pemasaran adalah ujung tombak produk yang akan ditawarkan, dan promosi sebagai salah satu tindakan pemasaran juga berperan penting dalam memperkenalkan produk yang akan ditawarkan kepada nasabah atau calon nasabah. Peranan kegiatan ini merupakan sarana dalam meningkatkan jumlah nasabah suatu Bank. Itulah yang mendorong penulis untuk memilih judul: Peranan Promosi Dalam Meningkatkan Jumlah Nasabah Tabungan Pada Bank Nagari Cab. Sawahlunto.

Perumusan Masalah

Sesuai dengan judul diatas, maka masalah yang dibahas dalam Penelitian ini dirumuskan sebagai berikut: Jenis Promosi apa yang dilakukan oleh Bank Nagari Cabang Sawahlunto dan sejauh mana peranannya didalam meningkatkan jumlah nasabah tabungan?

\section{METODE PENGUMPULAN DATA}

Dalam pengumpulan data penulis menggunakan dua cara yaitu :

a. Riset lapangan (Field research)

Yaitu peninjauan langsung ke objek penelitian yang dipilih untuk meneliti hasil data sekunder. Penelitian langsung kelapangan ini akan dapat membantu penulis untuk melengkapi data yang diperlukan. Adapun cara riset lapangan ini adalah dengan mewawancarai lansung pihak-pihak yang berkepentingan dalam hal ini adalah perusahaan atau instansi yang terkait.

b. Riset perpustakaan (Library research)

Yaitu penyelidikan yang dilakukan melalui kepustakaan ataupun bukubuku ilmiah dan tulisan-tulisan yang ada hubunganya dengan pembahasan yang dilakukan. Penelitian kepustakaan ini bersifat teorotis dimana dapat mengaplikasikanya dengan teori-teori yang berhubungan dengan penulisan ini. Serta sebagai landasan untuk informasi dalam rangka mendapatkan data sekunder.

\section{Teknik Analisa Data}

Teknik pengelolaan dan analisa data yang digunakan adalah teknik deskriptif analisis yaitu metode penelitian dengan mengumpulkan dan menyajikan data disertai analisis yang dapat memperjelas gambaran mengenai objek yang diteliti. Data yang digunakan dalam penelitian ini adalah data yang berhasil diperoleh, dikumpulkan selama penelitian, kemudian diproses untuk dianalisis lebih lanjut dengan mengunakan dasar-dasar teori yang ada sehingga dapat memperjelas gambaran mengenai objek yang diteliti. 


\section{LANDASAN TEORI \\ Pengertian Bank}

Dalam pembicaraan sehari-hari, Bank dikenal sebagai lembaga keuangan yang kegiatan utamanya menerima simpanan giro, tabungan dan deposito. Kemudian Bank dikenal sebagai tempat untuk meminjam uang (kredit) bagi masyarakat yang membutuhkannya. Disamping itu Bank juga dikenal sebagai tempat untuk menukar uang, memindahkan uang atau menerima segala bentuk pembayaran dan setoran seperti pembayaran listrik, telepon, air, pajak, uang kuliah dan pembayaran lainya.

Berdasarkan pasal 1 Undang - Undang No. 10 Tahun 1998 tentang perubahan Undang - Undang No. 7 Tahun 1992 tentang Perbankan. Definisi Bank adalah badan usaha yang menghimpun darimasyarakat dalam bentuk simpanan dan menyalurkan kembali kepada masyarakat dalam rangka meningkatkan taraf hidup rakyat banyak. Strategi bank dalam menghimpun dana adalah dengan memberikan penarik bagi nasabahnya berupa balas jasa yang menarik dan menguntungkan. Balas jasa tersebut dapat berupa bunga bagi bank yang berdasarkan prinsip konvensional dan bagi hasil untuk Bank yang berdasarkan prinsip syariah.

Kegiatan- kegiatan perbankan adalah sebagai berikut:

\section{Menghimpun dana dari masyarakat (Funding) dalam bentuk:}

a. Simpanan Giro (Demand Deposit) yaitu merupakan simpanan pada Bank diamana penarikannya dapat dilakukan setiap saat dengan mengunakan Bilyet Giro.

b. Simpanan Tabungan (Saving Deposit) yaitu simpanan pada Bank yang penarikannya dapat dilakukan dengan slip penarikan, buku tabungan, kartu ATM atau sarana penarikan lainnya.

c. Simpanan Deposito (Time Deposit) yaitu simpanan pada Bank yang penarikannya sesuai jangka waktu (jatuh tempo) dan dapat ditarik dengan bilyet deposito atau sertifikat deposito.

\section{Menyalurkan dana ke masyarakat (Lending) dalam bentuk kredit.}

Pasal 1 Undang-Undang Perbankan No 10 tahun 1998, yang menjelaskan tentang: Kredit adalah penyediaan uang atau tagihan yang dapat dipersamakan dengan itu bedasarkan persetujuan atau kesepakatan pinjam meminjam antara bank dengan pihak lain yang mewajibkan pihak peminjam untuk melunasi hutangnya setelah jangka waktu tertentu dengan pemberian bunga.

Adapun jenis kredit yang disediakan oleh Bank Nagari sebagai berikut:

a. Kredit Investasi, merupakan kredit yang diberikan kepada para investor untuk investasi yang penggunaannya jangka panjang.

b. Kredit Modal Kerja, merupakan kredit yang diberikan untuk membiayai kegiatan suatu usaha dan biasanya bersifat jangka pendek guna memperlancar transaksi perdagangan.

c. Kredi Usaha Kecil Informal,adalah pinjaman yang diberikan oleh Bank Nagari BPD Sumatera Barat kepada Usaha Mikro perorangan, anggota koperasi anggota binaan BDS dan kelompok usaha yang bergerak pada semua sektor ekonomi baik Modal kerja maupun investasi. 
d. Kredit Rekening Koran, adalah kredit diberikan untuk modal kerja debitur dan calon debitur baik Usaha Perorangan maupun Badan Usaha/Badan Hukum diberbagai sektor ekonomi.

e. Kredit Kepemilikan Rumah, adalah kredit diberikan dalam membantu masyarakat memperoleh perumahan / tempat hunian yang layak dan keperluan penyediaan dana tunai sepanjang terkait dengan nilai bangunan / rumah dimaksud.

f. Kredit kepada BPR, adalah kredit diberikan oleh Bank Nagari kepada Bank Perkreditan Rakyat dalam bentuk Kredit Modal Kerja dan Kredit Investasi.

g. Kredit Tenaga Kerja Indonesia (KTKI) adalah kredit yang diberikan kepada Calon Tenaga Kerja Indonesia (TKI) yang akan bekerja di Luar Negeri.

h. Kredit Modal Keja Kontraktor (KMKK) adalah pinjaman khusus dalam bentuk modal kerja yang diberikan Bank Nagari kepada perusahaan kontraktor ataupun sub kontraktor.

i. Kredit Personal, Kredit yang diberika kepada personal atau seseorang yang pengembaliannya dapat diangsur sesuai dengan kemampuan, dan silahkan digunakan sesuai dengan kebutuhan.

Adapun unsur-unsur yang terkandung dalam pemberian suatu fasilitas kredit menurut Kasmir (2003: 94) adalah sebagai berikut :

a. Kepercayaan

Yaitu keyakinan pemberi kredit bahwa prestasi yang diberikannya baik dalam bentuk uang, barang, atau jasa akan benar - benar diterimanya kembali dalam jangka waktu tertentu dimasa yang akan datang.

b. Kesepakatan

Disamping unsur percaya didalam kredit juga mengandung unsur kesepakatan antara pemberi kredit dengan penerima kredit. Kesepakatan ini dituangkan dalam suatu perjanjian dimana masing-masing pihak menandatangani hak dan kewajibanya masing-masing.

c. Jangka Waktu

Setiap kredit yang diberikan memiliki jangka waktu tertentu,jangka waktu ini mencakup masa pengembalian kredit yang telah disepakati. Hampir dapat dipastikan bahwa tidak ada kredit yang tidak memiliki jangka waktu.

d. Resiko

Adanya suatu tenggang waktu pengembalian akan menyebabkan suatu risiko tidak tertagihnya suatu kredit. Resiko ini merupakan tanggungan bank,baik resiko yang sengaja atau tidak sengaja yang dilakukan oleh nasabah.

e. Balas jasa

Merupakan keuntungan atas pemberian suatu kredit atau jasa yang disebut dengan bunga.

3. Memberikan jasa-jasa Bank lainnya (service) antara lain:

a. Menerima setoran-setoran; Pembayaran pajak, telpon, air, dan listrik

b. Melayani pembayaran:gaji/pensiun, deviden dan kupon

c. Transfer (Kiriman Uang) 


\section{d. Inkaso (Collection)}

e. Kliring (Clearing)

f. Save Deposit Box merupakan jasa penyimpanan dokumen

g. Letter Of Credit, Traveller Cheque

h. Jasa-jasa lainnya

\section{Pengertian Promosi}

Produk sudah diciptakan, harga juga sudah ditetapkan, dan tempat (lokasi dan layout sudah disediakan), artinya produk sudah benar-benar siap untuk di jual. Agar produk tersebut laku dijual ke masyarakat atau nasabah, maka masyarakat perlu tahu kelebihan produk tersebut, berikut manfaat, harga, di mana didapat diperoleh dan kelebihan produk dibandingkan pesaing. Cara untuk memberitahukan kepada masyarakat adalah melalui sarana promosi. Artiya, keputusan terakhir bank harus mempromosikan produk tersebut seluas mungkin ke nasabah.

Promosi merupakan kegiatan marketing mix yang terakhir. Kegitan ini merupakan kegiatan yang sama pentingnya dengan ketiga kegiatan di atas, baik produk, harga dan lokasi. Dalam kegiatan ini setiap bank beruasaha untuk mempromosikan seluruh produk dan jasa yang dimilikinya baik langsung maupun tidak langsung. Tanpa promosi jangan diharapkan nasabah dapat mengenal bank.

Oleh karena itu, promosi merupakan sarana yang paling ampuh untuk menarik dan mempertahankan nasabahnya. Salah satu tujuan promosi bank adalah menginformasikan segala jenis produk yang ditawarkan dan berusaha menarik calon nasabah yang baru kemudian promosi juga berfungsi mengingatkan nasabah akan produk, promosi juga ikut mepengaruhi nasabah untuk membeli dan akhirnya promosi juga akan menigkatkan citra serta mana baik Bank dimata para nasabahnya. Dalam praktiknya paling tidak ada empat macam sarana promosi yang dapat digunakan oleh setiap bank dalam mempromosikan baik produk maupun jasanya. Pertama, promosi melalui periklanan (advertising). Kedua, melalui promosi penjualan (sales romotion), ketiga melalui Publisitas (publicity) dan keempat adalah promosi yang dilakukan melalui penjualan pribadi (personal selling).

Sama halnya Kotler (2005: 264-312), mengatakan bahwa unsur bauran promosi (promotion mix) terdiri atas lima perangkat utama, yaitu :

1) Advertising

Merupakan semua penyajian non personal, promosi ide-ide, promosi produk atau jasa yang dilakukan sponsor tertentu yang dibayar.

2) Sales Promotion

Berbagai insentif jangka pendek untuk mendorong keinginan mencoba atau membeli suatu produk atau jasa.

3) Public relation and publicity

Berbagai program untuk mempromosikan dan atau melindungi citra perusahaan serta produk individualnya.

4) Personal Selling

Interaksi langsung dengan calon pembeli atau lebih untuk melakukan suatu presentasi, menjawab langsung dan menerima pesanan. 
5) Direct marketing

Penggunaan surat, telepon, faksimil, e-mail dan alat penghubung nonpersonal lain untuk berkomunikasi secara dengan atau mendapatkan tanggapan langsung dari pelanggan tertentu dan calon pelanggan.

Masing-masing sarana promosi ini memiliki tujuan sendiri-sendiri. Misalnya, untuk menginformasikan tentang keberadaan produk dapat dilakukan melalui iklan. Untuk mempengaruhi nasabah dilakukan melalui sales promotion serta untuk memberikan citra perbankan dapat dilakukan melalui publisitas.

Bagi bank promosi penjualan dapat dilakukan melalui :

1. Pemberian bunga khusus untuk jumlah dana yang relative besar walaupu hal ini akan mengakibatkan persaingan tidak sehat.

2. Pemberian insentif kepada setiap nasabah yang memiliki simpanan dengan saldo tertentu.

3. Pemberian cinderamata, hadiah serta kenang-kenangan lainnya kepada nasabah yang loyal.

4. Promosi penjualan lainnya.

Sama seperti halnya dengan iklan, promosi penjualan juga memiliki program tersendiri. Dalam praktiknya program promosi penjualan memiliki tiga macam cara, yaitu :

1. Promosi Konsumen, seperti penggunaan kupon, sample produk, atau bentuk undian.

2. Promosi Dagang yaitu berupa bantuan peralatan atau insentif.

3. Promosi Wiraniaga, melalui kontes penjualan.

\section{Macam-macam promosi}

A. Advertising (Periklanan)

Iklan merupakan sarana promosi yang digunakan oleh bank guna menginformasikan segala sesuatu produk yang dihasilkan oleh bank. Informasi yang diberikan seperti manfaat produk, harga produk serta keunggulankeunggulan produk dibandingkan produk sejenis yang ditawarkan oleh pesaing. Tujuan promosi lewat iklan adalah berusaha menarik dan mempengaruhi nasabah lama serta calon nasabahnya.

Iklan yang dibuat haruslah seefektif dan efisien mungkin sehingga maksud dan tujuan dari iklan tersebut bisa tersampaikan dengan baik. Agar iklan yang dijalankan efektif dan efisien maka harus memperhatikan tahapan-tahapan berikut:

1. Identifikasi pasar sasaran dan motif pembeli

2. Tentukan misi yang menyangkut sasaran penjualan dan tujuan periklanan (mission)

3. Anggaran iklan yang ditetapkan (money)

4. Merancang pesan yang akan disampaikan (message)

5. Memilih media yang akan digunakan (media)

6. Mengukur dampak/evaluasi terhadap hasil yang telah dicapai dari pemasangan suatu iklan (measurement)

Ciri-ciri yang terdapat pada suatu periklanan adalah:

a. Public Presentation (penyajian di muka umum) 
Iklan merupakan suatu sarana komunikasi yang sangat bersifat umum dan menawarkan pesan yang sama kepada banyak orang.

b. Pervasiveness (penyerahan menyeluruh)

Iklan merupakan medium yang diserap secara menyeluruh dan memungkinkan pihak perusahaan untuk mengulangi pesannya itu secara berulang-ulang, diharapkan dengan pengulangan pesan tersebut akan memberikan pengaruh signifikan terhadap konsumen.

c. Expresiveness (daya tangkap yang kuat)

Periklanan memberikan peluang untuk menampilkan perusahaan serta produknya dengan cara yang amatmengesankan dengan penggunaan cetakan, bunyi dan warna secara pandai.

d. Impresonality (kurang kepribadian)

Periklanan senantiasa bersifat umum, sehingga daya meyakinkan dan mengungkapkan tentang produk tersebut secara terperinci masih dirasakan kurang. Oleh karenanya iklan masih kurang mampu menyentuh konsumen secara personal.

Tujuan dari penggunaan dan pemilihan media iklan sendiri tergantung dari tujuan masing-masing bank yang bersangkutan, karena masing-masing media memiliki tujuan yang berbeda-beda. Oleh karena itu ada beberapa macam tujuan dari penggunaan iklan sebagai media promosi, yaitu:

1. Untuk pemberitahuan tentang segala sesuatu yang berkaitan dengan produk dan jasa yang dimiliki oleh suatu Bank. Seperti peluncuran produk baru, manfaat produk atau dimana produk tersebut bisa didapatkan, keuntungan dan kelebihan suatu produk atau informasi lainnya. Selain itu iklan juga bertujuan untuk memberitahukan tentang pembukaan kantor cabang atau kantor kas baru, lokasi-lokasi ATM, serta penggunaan teknologi terbaru dari perbankan.

2. Untuk mengingatkan kembali kepada nasabah tentang keberadaan atau keunggulan jasa bank yang ditawarkan. Hal ini dilakukan karena banyaknya saingan yang masuk sehingga nasabah perlu diingatkan agar nasabah tidak berpaling kepada bank lain.

3. Untuk menarik perhatian dan minat para nasabah baru dengan harapan akan memperoleh daya tarik dari para calon nasabah baru. Diharapkan mereka akan mencoba untuk membeli atau menggunakan produk yang ditawarkan atau paling tidak para calon nasabah yang baru sudah mengerti tentang kehadiran produk tersebut dan suatu hari mereka akan mencobanya.

4. Untuk mempengaruhi nasabah saingan agar berpindah ke bank yang mengiklankan. Selain untuk nasabah yang sudah menjadi nasabah bank yang bersangkutan iklan tersebut juga diharapkan akan mempengaruhi nasabah bank lain sehingga mereka berpindah kepada bank yang mengeluarkan iklan.

5. Untuk membangun citra perusahaan jangka panjang baik untuk produk yang dihasilkan ataupun untuk nama baik persahaan. 
Untuk memilih media yang akan digunakan untuk beriklan harus melakukan berbagai pertimbangan agar iklan yang dibuat bisa efektif. Pertimbangan yang perlu dilakukan adalah:

a. Jangkauan media yang akan digunakan termasuk oplah (jumlah yang diterbitkan atau ditayangkan)

b. Sasaran atau konsumen yang dituju

c. Biaya yang akan dikeluarkan

Iklan terbagi menjadi beberapa jenis

1. Berdasarkan manfaat:

a) Institutional advertising

Periklanan untuk pembentukan citra organisasi atau perusahaan dalam jangka panjang.

b) Brand advertising

Periklanan untuk memantapkan pada merek tertentu dalam jangka panjang.

c) Classified advertisin

Periklanan untuk penyebaran informasi tentang penjualan, jasa dan peristiwa.

d) Sales advertising

Periklanan untuk pengumuman penjualan khusus.

2. Berdasarkan Klasifikasi:

a) National advertising

Periklanan yang dilaksanakan oleh produsen dari suatu barang industri maupun barang konsumsi yang disebarkan secara nasional dan regional.

b) Local advertising

Periklanan yang dibatasi oleh lingkungan geografis, yaitu apabila produk yang akan ditawarkan bersifat lokal suatu daerah tertentu.

c) Consumers advertising periklanan yang ditujukan langsung kepada konsumen akhir.

d) Trade advertising

Periklanan untuk membantu manufaktur yang dapat digunakan untuk mengiklankan produk yang dihasilkan.

e) Industrial advertising

Periklanan untuk mencapai manufaktur lain yang dapat digunakan produk yang telah diiklankan.

f) Primary demand advertising

Periklanan yang ditujukan untuk mempromosikan produk, tanpa menonjolkan merek penjualnya.

g) Selective demand advertising

Periklanan yang ditujukan untuk membangkitkan selektive demand secara jelas menyebutkan dan brand name dari produk tersebut.

Jenis-jenis media yang dapat digunakan sebagai sarana iklan, yaitu:

1. Surat kabar dan majalah, merupakan media periklanan yang lebih efektif dalam memilih pasar sasaran, meskipun biaya relatif mahal tetapi memiliki masa pakai yang panjang. 
2. Surat pos langsung

3. Radio, merupakan media periklanan yang cukup fleksibel, sebab pemasangan iklan dapat menyesuaikan dengan acara, waktu serta sasaran yang dituju.

4. Televisi, media yang digunakan untuk melakukan periklanan secara nasional, regional ataupun local.

5. Papan reklame

6. Spanduk

7. Penyebaran brosur di tempat-tempat umum

8. dan berbagai media lainnya.

Agar iklan yang dijalankan efektif dan efisien maka perlu dilakukan program pemasaran yang tepat. Dalam praktiknya program periklanan yang harus dilalui adalah sebagai berikut :

a. Identifikasikan pasar sasaran dan motif pembeli

b. Tentukan misi yang menyangkut sasaran penjualan dan tujuan periklanan

c. Anggaran iklan yang ditetapkan

d. Merancang pesan yang akan disampaikan

e. Memilih media yang akan digunakan

f. Mengukur dampak dari iklan

Untuk melakukan promosi melalui iklan perlu menggunakan beberapa sarana media. Penggunaan sarana media ini dilakukan dengan berbagai pertimbangan. Kemudian pertimbangan penggunaan media yang akan dipakai untuk pemasangan iklan di suatu media antara lain :

1. Jangkauan media yang akan digunakan, termasuk oplah (jumlah yang diterbitkan). Jangkauan media maksudnya wilayah yang telah dimasuki oleh media yang akan digunakan.

2. Sasaran atau konsumen yang akan dituju, pemilihan ini didasarkan pada sasaran pembaca, karena setiap mdia memiliki sasaran pembaca tersendiri.

3. Biaya yang akan dikeluarkan, artinya, biaya untuk pemasangan iklan di meia yang dituju.

\section{Keunggulan promosi melalui iklan, antara lain :}

1. Presentasi Publik, artinya iklan menawarkan pesan yang sama kepada banyak orang.

2. Pervesivenes yaitu memungkinkan perusahaan untuk mengulang pesan berulang kali.

3. Amplied Expressiveness yaitu berpeluang untuk mendramatisir produk melalui pemanfaatan suatu warna atau bentuk produk.

4. Impersonality maksudnya konsumen atau nasabah tidak wajib untuk memperhatikan dan merespon iklan sekarang.

B. Sales promotion (promosi penjualan)

Sales promotion merupakan promosi yang digunakan untuk meningkatkan penjualan melalui potongan harga atau hadiah pada waktu tertentu terhadap barang-barang tertentu pula. Tujuan promosi penjualan ini adalah untuk meningkatkan penjualan atau meningkatkan jumlah nasabah. Promosi penjualan ini dilakukan untuk menarik nasabah untuk segera membeli setiap produk atau 
jasa yang di tawarkan. Kegiatan ini bersifat jangka pendek dan tidak dilakukan berulang-ulang serta tidak rutin, yang ditujukan untuk mendorong lebih kuat mempercepat respon pasar yang ditargetkan sebagai alat lainnya dengan menggunakan bentuk yang berbeda.

Karena waktunya singkat makapromosi penjualan ini harus dibuat semenarik mungkin agar nasabah tertarik untuk membeli. Promosi penjualan bisa dilakukan melalui pemberian diskon, kontes, kupon, atau sampel produk. Maka secara tidak langsung hal tersebut akan memberikan tiga manfaat bagi promosi penjualan, yaitu:

1. Komunikasi, yaitu memberikan informasi yang dapat menarik dan mempengaruhi perhatian nasabah untuk membeli.

2. Insentif, yaitu memberikan dorongan dan semangat kepada nasabah untuk segera membeli produk yang ditawarkan.

3. Invitasi, yaitu mengharapkan nasabah segera merealisasikan pembelian produk perbankan.

Adapun tahapan Promosi penjualan adalah sebagai berikut:

1. Menentukan tujuan yang akan dicapai dari program promosi penjualan tersebut

2. Menyeleksi alat-alat atau apa yang akan ditawarkan dari program promosi penjualan tersebut

3. Menyusun program promosi penjualan yang sesuai

4. Melakukan pengujian pendahuluan atas program

5. Melaksanakan dan mengendalikan program

6. Mengevaluasi hasil akhir dari program promosi penjualan tersebut

Faktor-faktor yang perlu dipertimbangkan dalam promosi penjualan

a. Establish the sales

b. Promotion objective and select the sales promotion tools (menetapkan dan menyeleksi promosi penjualan berdasarkan tujuan dari promosi penjualan) Perusahaan mengidentifikasi terlebih dahulu apa tujuan yang ingin dicapai dari promosi penjualan yang ingin dilakukan, kemudian menetapkan jenis promosi penjualan yang paling tepat untuk mencapai tujuan tersebut.

c. Size of intensives (besarnya insentif)

Berupa besaran insentif yang akan diberikan kepada pelanggan. Misalkan suatu bank syariah melakukan promosi penjualan berupa pemberian hadiah kepada nasabah, maka bank syariah tersebut harus menghitung hadiah apa saja yang akan diberikan kepada nasabah.

d. Duration and timing of promotion (lamanya dan jangka waktu promosi. Ini biasa kita lihat yaitu dengan pengundian hadiah pada bank syariah yang memiliki beberapa periode waktu.

e. Total sales promotion budget (besarnya anggaran penjualan keseluruhan yang tersedia)

f. Competition (kompetisi)

g. Market condition (kondisi pasar)

Bagi perbankan promosi penjualan dapat dilakukan dengan cara:

1. Pemberian bunga khusus (special rate)

Biasanya ini dilakukan oleh bank terhadap nasabahnya yang memiliki 
dana dalam jumlah besar di bank yang bersangkutan. Meskipun hal ini terkadang mengakibatkan persaingan yang tidak sehat di antara bank.

2. Pemberian intensif

Hal ini biasanya di berikan kepada nasabah yang memiliki sejumlah saldo tertentu. Misalkan kepada nasabah yang memiliki saldo di atas jumlah tertentu, ditiadakan biaya administrasi atas tabungannya. Atau nasabah yang memilih layanan perbankan prioritas maka mendapatkan beberapa kemudahan atau fasilitas tambahan dibandingkan nasabah biasa, misalkan antrian khusus yang diberikan kepada nasabah prioritas.

3. Pemberian cinderamata, hadiah serta kenang-kenangan lainnya kepada nasabah yang setia. Misalkan program hadiah umroh yang diberikan oleh Bank Nagari kepada nasabah Tabungan Tahari

4. dan promosi penjualan lainnya.

Sama halnya dengan dengan kegiatan periklanan, maka promosi penjualan juga memiliki program tersendiri. dalam praktiknya program promosi penjualan memiliki tiga macam cara, yaitu:

1. Promosi konsumen, seperti penggunaan kupon, sampel produk, hadiah, atau bentuk undian berhadiah lainnya.

2. Promosi dagang, yaitu berupa bantuan peralatan atau insentif.

3. Promosi wiraniaga melalui kontes penjualan.

\section{Publicity (publisitas)}

Merupakan promosi yang dilakukan untuk meningkatkan citra bank didepan para calon nasabah atau nasabahnya melalui kegiatan sponsorship terhadap suatu kegiatan amal atau sosial atau olahraga. Promosi yang ketiga ini merupakan kegiatan promosi untuk memancing nasabah melalui kegiatan seperti pameran, bakti sosial serta kegiatan lainnya.

Kegiatan publisitas dapat meningkatkan pamor bank dimata para nasabahnya. Oleh karena itu, publisitas perlu diperbanyak lagi. Tujuannya adalah agar nasabah mengenal bank lebih dekat. Dengan ikut kegiatan tersebut, nasabah akan selalu mengingat bank tersebut dan diharapkan akan menarik nasabah. Kegiatan publisitas dapat dilakukan melalui :ikut pameran, ikut kegiatan amal, ikut bakti sosial, ikut kegiatan sponsorship dan lain-lain.

D. Personal selling (penjualan pribadi)

Merupakan promosi yang dilakukan melalui pribadi-pribadi karyawan bank dalam melayani, serta ikut mempengaruhi nasabah. Kegiatan promosi yang keempat ini adalah penjualan pribadi atau personal selling. Dalam dunia perbankan penjualan pribadi secara umum dilakukan oleh seluruh pegawai bank, mulai dari cleaning service, satpam hingga pejabat bank.

Personal selling juga dilakukan melalui perekrutan tenaga-tenaga salesman dan salesgirl untuk melakukan penjualan door to door. Penjualan secara personal selling akan memberikan beberapa keuntungan bank,yaitu:

1. Bank dapat langsung bertatap muka dengan nasabah atau calon nasabah, sehingga dapat langsung menjelaskan tentang produk Bank kepada nasabah secara rinci. 
2. Dapat memperoleh informasi langsung dari nasabah tentang kelemahan produk kita langsung dari nasabah, terutama dari keluhan yang nasabah sampaikan termasuk informasi dari nasabah tentang Bank lain.

3. Petugas Bank dapat langsung mempengaruhi nasabah dengan berbagai argumen.

4. Memungkinkan hubungan terjalin akrab antara pihak Bank dengan nasabah.

5. Petugas Bank yang memberikan pelayanan merupakan citra Bank yang diberikan kepada nasabah apabila pelayanan yang diberikan baik dan memuaskan.

6. Membuat situasi seolah-olah mengharuskan nasabah mendengarkan, memperhatikan dan menanggapi Bank.

E. Direct marketing

Promosi jenis ini dalam penggunaan menggunakan surat, telepon, faksimil, e-mail dan alat penghubung nonpersonal lain untuk berkomunikasi secara langsung dengan mendapatkan tanggapan langsung dari pelanggan tertentu dan calon pelanggan.

Promosi yang dilakukan dalam meningkatkan jumlah nasabah tabungan pada Bank Nagari Cab. Sawahlunto

Promosi sangatlah bermanfaat bagi pertumbuhan suatu perbangkan, bicara soal manfaat, kontribusi advertising bagi perusahaan jelas tidak dapat disepelekan. Bahkan periklanan memegang kunci penting, terutama dalam hal pelaksanaan promosi perusahaan. Didalam aktivitas perusahaan, advertising/periklanan merupakan bagian dari promotion mix/ bauran promosi. Masing-masing alat promosi tersebut menggunakan alat/cara berbeda untuk mencapai tujuannya. Penerapan bauran promosi total, diharapkan bisa mempercepat pencapaian tujuan/meningkatkan efektivitas pencapaian tujuan pemasaran. Dalam hal ini Bank Nagari Cab. Sawahlunto mengeluarkan biaya promosi untuk meningkatkan jumlah nasabah tabungan.

Pada tabungan Tabanas, Tahari, Simpeda, Simpeda II, Sikoci, ABD, dan TabunganKu pada umumnya dalam melakukan promosi untuk meningkatakan jumlah nasabah tabungannya menggunakan jenis promosi Advertising, Sales Promotion, Publisitas, Personal Selling, dan Direct Marketing. Pada bebrapa jenis tabungan ini ada bebrapa jenis tabungan yang melakukkan promosi secara khusus.

Seperti Pada tabungan Haji Tahari Mabrur, untuk colon nasabah haji Bank Nagari mengeluarkan biaya promosi pencetakan buku panduan haji, pemberian gift serta biaya promosi lainnya. Selain itu penelitian ini juga untuk mengetahui bentuk promosi Tabungan Haji Bank Nagari (TAHARI) pada Bank Pembangunan Daerah Sumatera Barat Cabang Sawahlunto/Sijunjung dan tantangan yang dihadapi oleh Bank Nagari Cabang Sawahlunto/Sijunjung dalam mempromosikan produk tabungan Haji Bank Nagari (TAHARI). Adapun promosi yang dilakukan adalah Bank Nagari Cabang Sawahlunto/Sijunjung menerapkan 3 (tiga) bentuk Promosi Tabungan Haji Bank Nagari (TAHARI) yaitu : Periklanan (Advertising), promosi penjualan (Sales Promotion), dan publisitas (Publicity). Media periklanan 
(Advertising) yang digunakan oleh Bank Nagari Cabang Sawahlunto/Sijunjung adalah media elektronik, media cetak, brosur, spanduk, dan sponsor.

Promosi penjualan (Sales Promotion), Bank Nagari menerapkan promosi konsumen dengan memberikan fee dan pemberian stiker-stiker secara gratis dan promosi dagang dengan pemberian souvenir gratis dan pengadaan acara-acara perlombaan agama yang berkaitan dengan pelaksanaan haji. Publisitas (Publicity), Bank Nagari menggunakan publisitas produk tentang berbagai keuntungan yang diperoleh oleh calon nasabah Tabungan (TAHARI) dan publisitas programprogram Bank Nagari seperti senam pagi antara nasabah dengan karyawan Bank Nagari. Tantangan yang dihadapi adalah persaingan antar bank dan produk Tabungan TAHARI yang merupakan produk baru bagi Bank Nagari. Segala promosi tersebut dilakukan oleh karena tabungan Haji ini adalah tabungan yang sifatnya tidak dapat di ambil dan hanya dapat diguankan jika tabungan sudah mencapai pada jumlah yang ditentukan. Hal ini tentu saja membuat para pelaku perbankan berlomba untuk mendapatkan nasabah calon haji. Selain itu tabungan haji ini juga berjumlah cukup besar dan jangka waktu dana dapat tersimpan cukup lama, tentu saja hal ini dapat dijadikan sebagai produktivitas perbankan atau dalam kata lain dana tersebut dapat di gunakan untuk pemberian kredit.

Sedangkan pada tabungan Sikoci, promosi yang digunakan adalah memberikan sponsor terhadap kegiatan-kegiatan sosial dan promosi berupa spanduk pada kegiatan tersebut. Selain itu pada jenis tabungan ini juga pernah dilakukan promosi secara advertising, personal selling, publisitas, dan direct marketing. Akan tetapi promosi yang dilakukan tidak begitu gencar. Promosi juga dilakukan melalui pemberian cendera mata kepada nasabah yang berkemampuan baik dalam berinvestasi. Selain itu biaya promosi dikeluarkan untuk mengharapkan peningkatan pada jumlah nasabah tabungan, dalam bentuk pembelian souvenir-sovenir, beasiswa, menjadi donator dalam sebuah acara social, serta sosialisasi secara langsung pada sekolah- sekolah. Bahkan hampir semua jenis promosi dilakukan pada Bank Nagari Cab. Sawahlunto.

Promosi pada jenis tabungan TabunganKu adalah Advertising, beriklan dengan mengutamakan penguraian tentang syarat yang mudah dan biaya yang sangat minimal. Bahkan pada tabungan ini tidak dikenakan biaya per bulan dan biaya ATM. TabunganKu adalah tabungan yang di khususkan untuk siswa dan jumlah setoran minimal pun sangat kecil, hal ini dapat mempermudah siswa-siawa sekolah dasar dalam membiasakan menabung sejak dini.

Akan tetapi pada Tabungan Pembangunan Nasional (Tabanas), merupakan bentuk tabungan yang tidak terikat oleh jangka waktu dengan syarat penyetoran dan pengambilan, tabanas pertama kali diatur pada tahun 1971. Oleh karena itu Tabanas telah dikenal olah masyarakat sawahlunto sejak lama dan pada tabungan ini tidak perlu dilakukan promosi yang begitu besar karena sebagian besar produk tabungan ini di khususkan pada pegawai negeri wilayah Sumatra Barat. Dan ini juga dikarenakan Bank Nagari adalah Bank yang salah satu pemegang sahamnya adalah Pemerintah daerah Sumatra Barat.

Walaupun demikian peranan promosi hanya berkemungkinan sedikit berpengaruh terhadap jumlah nasabah tabungan pada Bank Nagari Cab. 
Sawahlunto. Hal ini dapat dilihat pada peningkatan dan penurunan yang terjadi pada tahun $2009,2010,2011$

Tabel 1

Jumlah nasabah tabungan pada Bank Nagari Cab. Sawahlunto

Tahun 2009

\begin{tabular}{|c|l|c|}
\hline No & \multicolumn{1}{|c|}{ Jenis Tabungan } & Jumlah Nasabah \\
\hline \hline 1 & Tabanas Umum & 4.500 \\
\hline 2 & Tabanas Pelajar & 178 \\
\hline 3 & Tabanas Pegawai & 460 \\
\hline 4 & Tahari Mabrur & 232 \\
\hline 5 & Simpeda & 4.000 \\
\hline 6 & Tabungan Simpeda II & 668 \\
\hline 7 & Tabungan Sikoci & 5.918 \\
\hline 8 & ABD & 9 \\
\hline 9 & TabunganKu & 1.222 \\
\hline & Jumlah & 17.187 \\
\hline
\end{tabular}

Tabel 2

Jumlah nasabah tabungan pada Bank Nagari Cab. Sawahlunto

Tahun 2010

\begin{tabular}{|c|l|c|}
\hline No & \multicolumn{1}{|c|}{ Jenis Tabungan } & Jumlah Nasabah \\
\hline \hline 1 & Tabanas Umum & 4.518 \\
\hline 2 & Tabanas Pelajar & 205 \\
\hline 3 & Tabanas Pegawai & 469 \\
\hline 4 & Tahari Mabrur & 232 \\
\hline 5 & Simpeda & 4.007 \\
\hline 6 & Tabungan Simpeda II & 675 \\
\hline 7 & Tabungan Sikoci & 5.926 \\
\hline 8 & ABD & 9 \\
\hline 9 & TabunganKu & 1.223 \\
\hline & Jumlah & 17.264 \\
\hline
\end{tabular}

Tabel 3

Jumlah nasabah tabungan pada Bank Nagari Cab. Sawahlunto

Tahun 2011

\begin{tabular}{|c|l|c|}
\hline No & \multicolumn{1}{|c|}{ Jenis Tabungan } & Jumlah Nasabah \\
\hline \hline 1 & Tabanas Umum & 4.524 \\
\hline 2 & Tabanas Pelajar & 204 \\
\hline 3 & Tabanas Pegawai & 469 \\
\hline 4 & Tahari Mabrur & 217 \\
\hline 5 & Simpeda & 4.904 \\
\hline 6 & Tabungan Simpeda II & 852 \\
\hline 7 & Tabungan Sikoci & 6.118 \\
\hline 8 & ABD & 9 \\
\hline 9 & TabunganKu & 134 \\
\hline & Jumlah & 17.431 \\
\hline
\end{tabular}


Dari tabel dapat diketahui tingkat jumlah nasabah pada tabungan Bank Nagari Cab. Sawahlunto mengalami fluktuasi naik turun setiap tahunnya. Secara keseluruhan jumlah nasabah memang terlihat mengalami kenaikan, akan tetapi jika dilihat secara lebih terperinci pada setiap jenis tabungan nampak beberapa tabungan yang mengalami penurunan jumlah nasabah. Tentu saja hal ini dikarenakan, peranan promosi tidak begitu signifikan terhadap semua jenis tabungan.

1. Pada tabungan Tabanas Umum, peningkatan jumlah nasabah dengan koefisien sebesar 0.24 artinya kegiatan promosi hanya mampu meningkatkan jumlah nasabah tabungan ini sebanyak 24 orang dalam tiga tahun terakhir.

2. Pada tabungan Tabanas Pelajar, penurunan jumlah nasabah dengan koefisien sebesar 0.1pada tahun terakhir dan peningkatan sebesar 0,26 pada tahun pertama artinya walaupun sudah dilakukan promosi belum tentu mampu meningkatkan jumlah nasabah tabungan ini,karena dalam hal ini jumlah nasabah berkurang dari tahun sebelumnya sebanyak 1 orang, dan bertambah kembali pada tahun berikutnya sebanyak 26 orang.

3. Pada tabungan Tabanas Pegawai, kegiatan promosi justru tidak berperan penting dalam meningkatkan jumlah nasabah pada tabungan ini.

4. Pada tabungan Tahari Mabrur, penurunan jumlah nasabah dengan koefisien sebesar 0.15 artinya walaupun sudah dilakukan promosi belum tentu mampu meningkatkan jumlah nasabah tabungan ini,karena dalam hal ini jumlah nasabah berkurang dari tahun sebelumnya sebanyak 15 orang.

5. Pada tabungan Simpeda, peningkatan jumlah nasabah dengan koefisien sebesar 9.04 artinya kegiatan promosi hanya mampu meningkatkan jumlah nasabah tabungan ini sebanyak 904 orang.

6. Pada tabungan Simpeda II, peningkatan jumlah nasabah dengan koefisien sebesar 1.84 artinya kegiatan promosi hanya mampu meningkatkan jumlah nasabah tabungan ini sebanyak 184 orang.

7. Pada tabungan Sikoci, peningkatan jumlah nasabah dengan koefisien sebesar 2.00 artinya kegiatan promosi hanya mampu meningkatkan jumlah nasabah tabungan ini sebanyak 200 orang.

8. Pada $\mathrm{ABP}$, kegiatan promosi justru tidak perperan penting dalam meningkatkan jumlah nasabah pada tabungan ini.

9. Pada Produk TabunganKu, penurunan jumlah nasabah dengan koefisien sebesar 10.89 artinya walaupun sudah dilakukan promosi belum tentu mampu meningkatkan jumlah nasabah tabungan ini,karena dalam hal ini jumlah nasabah berkurang dari tahun sebelumnya sebanyak 1089 orang. Walaupun pada tahun pertama pada tabungan ini mengalami pertambahan nasabah 1 orang.

Selain itu juga bisa dilihat dari perubahan grafik tersebut: 
Grafik Peningkatan dan Penurunan

Jumlah Nasabah Tabungan pada Tahun 2009, 2010, dan 2011

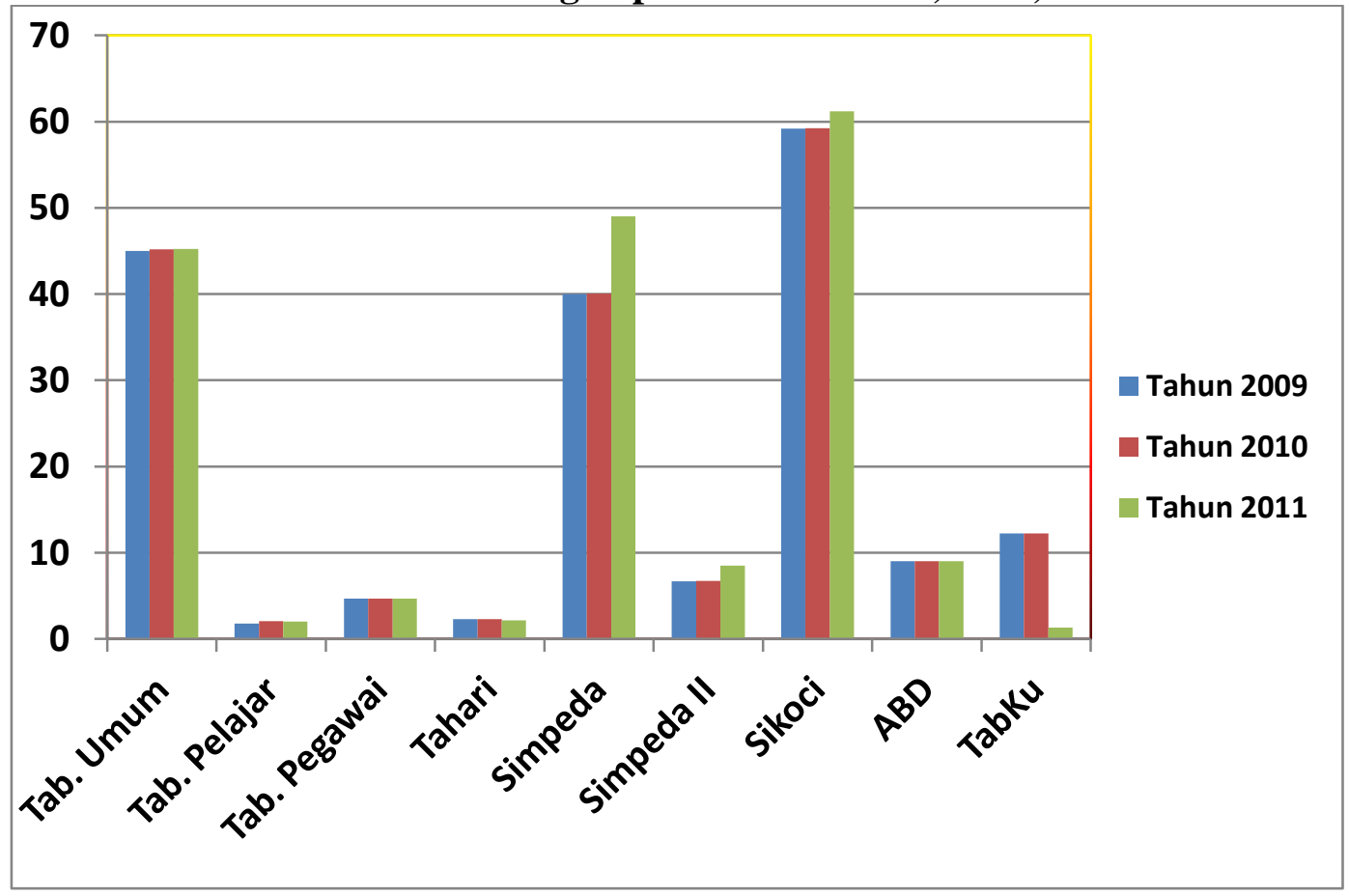

\section{KESIMPULAN}

Berdasarkan atas pemahaman teori dan pembahasan yang dituangkan pada bab-bab sebelumnya, dapat ditemukan beberapa kesimpulan sebagai berikut:

- Produk Bank Nagari dalam menghimpun dana masyarakat adalah dalam bentuk tabungan yang terdiri dari tabungan sikoci, tabungan Haji Tahari Mabrur, Simpeda, dan lain-lain.

- Dalam meningkatkan jumlah nasabah tabungan Bank Nagari Cab. Sawahlunto melakukan promotion Mix atau bauran promosi yakni: advertising, sales promotion, publicity, personal selling. Dalam hal lain mencakup pemberian undian-undian pada berbagai jenis tabungan, pemberian cendera mata, serta melakukan promosi dengan cara memberikan beasiswa terhadap pendidikan. Dalam arti kata biaya promosi belum berpengaruh secara signifikan terhadap peningkatan jumlah nasabah tabungan. Hal ini terlihat pada peningkatan dan penurunan jumlah nasabah dari tahun ke tahun.

\section{DAFTAR PUSTAKA}

Andika, A., \& Susanti, F. (2018). Pengaruh Marketing Mix Terhadap Keputusan Pembelian Parfum di Azzwars Parfum Lubeg Padang. https://doi.org/10.31227/osf.io/upgc3 
Aziz, N. (2019). Pengaruh Strategi Promosi Terhadap Keputusan Pembelian Yang Dimediasi Oleh Minat Beli Pada Konsumen Restoran KFC Cabang Khatib Sulaiman Padang. https://doi.org/10.17605/OSF.IO/V92TS

F., \& Afriyeni, A. (2019). Aktivitas Pemasaran Produk Tabungan Pada PT. Bank Pembangunan Daerah (BPD) Sumatera Barat Cabang Utama Padang. https://doi.org/10.31219/osf.io/tf2bz

Hidayati, R. R., \& Marlius, D. (2018). Aktivitas Promosi Dalam Meningkatkan Dana Pihak Ketiga Pada PT. Bank Perkreditan Rakyat (BPR) Batang Kapas Pesisir Selatan. https://doi.org/10.31227/osf.io/8dgqn

Marlius, D. (2017). Keputusan Pembelian Berdasarkan Faktor Psikologis Dan Bauran Pemasaran Pada PT. Intercom Mobilindo Padang. Jurnal Pundi. Volume 1. No. 1. Hal. 57-66. https://doi.org/10.31575/jp.v1i1.9

Marlius, D. (2016). Pengaruh Bauran Pemasaran Jasa Terhadap Minat Nasabah Dalam Menabung Pada Bank Nagari Cabang Muaralabuh. https://doi.org/10.31227/osf.io/vdqgx

Mayliza, R. (2019). Pengaruh Citra Perusahaan (Corporate Image) Dan Penanganan Keluhan (Complaint Handling) Terhadap Loyalitas Pelanggan (Loyality) Natasha Skin Care Di Kota Padang. https://doi.org/10.17605/OSF.IO/DF9XJ

Safitri, R. N., \& Marlius, D. (2017). Penerapan E-Banking Dalam Meningkatkan Jasa Dan Layanan Perbankan Di PT. Bank Rakyat Indonesia Cabang Padang. https://doi.org/10.31227/osf.io/gkv8t

Susanti, F. (2015). Pengaruh Bauran Promosi Terhadap Keputusan Klien Dalam Memilih Radio Carano Sebagai Media Promosi Iklan. https://doi.org/10.31227/osf.io/b9ws7

Susanti, F., \& Gunawan, A. C. (2019). Pengaruh Bauran Promosi Dan Harga Terhadap Keputusan Pembelian Produk Kosmetik Maybelline Di Kota Padang. https://doi.org/10.31227/osf.io/npjqh

Undang-Undang No 10 Tahun 1998 tentang perubahan Undang-Undang No. 7 Tahun 1992 tentang perbankan 
Widayati, R. (2019). Promotional Activities And Services Bank Nagari Kambang Increase In Customer. https://doi.org/10.17605/OSF.IO/MYAVT

Widayati, R. (2019). Upaya Meningkatkan Minat Untuk Menabung Pada PT. BPR Batang Kapas. https://doi.org/10.17605/OSF.IO/AEVW7

Widayati, R. (2019). Aktivitas Pemasaran Produk Simpanan PT. Bank Tabungan Negara (Persero)Tbk Kantor Cabang Padang. https://doi.org/10.17605/OSF.IO/3Z5YC

Widayati, R. (2019). Aktivitas Pemasaran Produk Tabungan Pada PT. Bpr Rangkiang Denai Payakumbuh Barat. https://doi.org/10.17605/OSF.IO/S3UZM 